\title{
Commentary: You get more than you give-Living donor lobar lung transplant
}

\author{
Victor van Berkel, MD, PhD \\ From the Department of Cardiovascular and Thoracic Surgery, University of Louisville School of Medicine, \\ Louisville, Ky. \\ Disclosures: Authors has nothing to disclose with regard to commercial support. \\ Received for publication June 22, 2019; accepted for publication June 24, 2019; available ahead of print Aug 9, \\ 2019. \\ Address for reprints: Victor van Berkel, MD, PhD, 201 Abraham Flexner Way, Suite 1200, Louisville, KY 40202 \\ (E-mail: victor.vanberkel@louisville.edu). \\ J Thorac Cardiovasc Surg 2019;158:1720 \\ $0022-5223 / \$ 36.00$ \\ Copyright (c) 2019 by The American Association for Thoracic Surgery \\ https://doi.org/10.1016/j.jtcvs.2019.06.087
}

For many end-stage lung diseases, lung transplantation remains the only available treatment. Over the last 30 years, the use of lung transplantation has grown worldwide, with a slow but consistent improvement in outcomes. ${ }^{1}$ Although the use of cadaveric donors is by far the most common means of performing lung transplants, in certain parts of the globe where cadaveric organ donation is rare, such as Japan, institutions have turned to living donor lobar transplants as a means of treating patients with end-stage disease. $^{2}$

The ability to longitudinally follow the lobar recipients and the living donors provides a unique opportunity to examine the impact of moving a portion of lung parenchyma from one person to another. In this issue of the Jour$n a l$, Kayawake and colleagues ${ }^{3}$ describe their 10-year experience in living donor lung transplantation, with a focus on the relative changes in pulmonary function both for their donors and their recipients. They found that 1 year after transplant, the lung transplant recipient pulmonary function test results were close to what was predicted given the volume of lung that was transplanted, but interestingly, the donor pulmonary function test results were significantly better than expected. The donors still had a loss in their lung function after donation, but the decrement in pulmonary function was less than would have been predicted on the basis of the volume of donation.

There is some precedent for this sort of finding after lung resection. Several groups have noted that after lobectomies for cancer, patients typically will have better pulmonary function test results than expected given the degree of resection that has occurred. ${ }^{4,5}$ This has been explained by the remaining lung "stretching" into the space vacated by the resected lung, resulting in improved pulmonary function without gaining lung tissue. Kayawake and colleagues ${ }^{3}$ found evidence for this in the current article, with computed tomography measurements of lung volume in the donors significantly increasing by 1 year postresection. In contrast, the lobes that were transplanted into the recipients did not

\section{References}

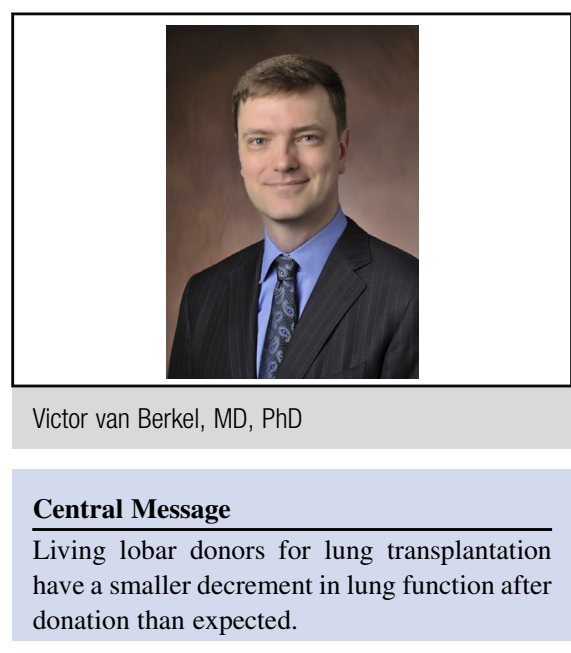

See Article page 1710.

dramatically change in volume over the first postoperative year, despite having even more space to "stretch" into. The cause for this lack of improvement is not clear, although the propensity for transplanted lungs to experience restrictive changes over time is perhaps not unexpected.

These data represent an interesting observation made by the authors over 10 years of experience with a very challenging operation. Conceivably, this observation could result in a broadening of the acceptable parameters for who could become a lobar donor for transplant, allowing patients with lower initial pulmonary functions to donate. The authors should be commended for their excellent outcomes and willingness to provide creative solutions for these patients who are otherwise without options.

1. Chambers DC, Cherikh WS, Goldfarb S, Hayes D Jr, Kucheryavaya AY, Toll AE, et al. The International Thoracic Organ Transplant Registry of the International Society for Heart and Lung Transplantation: thirty-fifth adult lung and heartlung transplant report-2018; focus theme: multiorgan transplantation. J Heart Lung Transplant. 2018;37:1169-83.

2. Date H, Sato M, Aoyama A, Yamada T, Mizota T, Kinoshita H, et al. Living-donor lobar lung transplantation provides similar survival to cadaveric lung transplantation even for very ill patients. Eur J Cardiothorac Surg. 2015;47:967-73.

3. Kayawake H, Chen-Yoshikawa TF, Hamaji M, Nakajima D, Ohsumi A, Aoyama A, et al. Acquired recipient pulmonary function is better than lost donor pulmonary function in living-donor lobar lung transplantation. J Thorac Cardiovasc Surg. 2019;158:1710-6.e2.

4. Kim HK, Lee YJ, Han KN, Choi YH. Pulmonary function changes over 1 year after lobectomy in lung cancer. Respir Care. 2016;61:376-82.

5. Kobayashi N, Kobayashi K, Kikuchi S, Goto Y, Ichimura H, Endo K, et al. Longterm pulmonary function after surgery for lung cancer. Interact Cardiovasc Thorac Surg. 2017;24:727-32. 